\title{
The Online Fashion Retail Complaint Management. A Case Study @ShopeeID.
}

\author{
Arissetyanto Nugroho \\ Department of Management, Universitas Mercu Buana, Indonesia
}

\begin{abstract}
Indonesia fashion retail e-commerce is a growing phenomenon; the growth of the e-commerce application @ShopeeID show the proposition delivered to the targeted market. Nevertheless, there is a lack of research conducted to explore fashion retail e-commerce attributes. Therefore, @ShopeeID tweet for the period September 2018 extracted for further exploratory factor analysis. There is 1761 tweet in the period; the findings show that@ShopeeID utilizing the channel for promotion, delivering the price, product, and the process for transaction in Shopee. The exciting finding shows that @ShopeeID could enhance the complaint management process, promote the responsiveness for the complaint delivered.
\end{abstract}

Keywords: @ShopeeID, Marketing Communication, Online Complaint

DOI: $10.7176 / \mathrm{JMCR} / 59-05$

Publication date: August $31^{\text {st }} 2019$

\section{Research Background}

Indonesia mobile telephone subscriber reached 458 million people, and it is the biggest in the ASEAN market (Euromonitor, 2019c). The position of the smartphone in Indonesia reach 56.6\% of households, rank the fifth after Malaysia, Cambodia, Thailand, and Vietnam. From these two indicators, we could predict that the future market for Indonesian connectivity via the mobile phone will still grow (Euromonitor, 2019b).

The growth of the e-commerce company in Indonesia is also speedy Tokopedia reaches 2907,1 absolute growth from 2013 until 2018 (Euromonitor, 2019a). Some of the most significant growth in e-commerce is online fashion e-commerce like Lazada and also Shopee (Euromonitor, 2019a).

The indicators show that e-commerce will grow and one of the industries that are growing in e-commerce is the fashion industry. Nevertheless, there still lack research that explores the uniqueness and the attributes of online fashion marketing communication.

Fashion is growing fast, and the consumers demand a fast and up to date mode (Sirumapea, Ramdhan, \& Masitoh, 2017). Therefore the fashion industry delivers a quick and responsive fashion mode to the consumers via the online channel and application. Fashion is not all about the summer and also the winter season, but fashion nowadays compared with newness. How cool the company delivers the newness of the fashion at first compared with the others.

Technology enables the producer and the consumer exchanging ideas and also information related to the fashion industry. Nevertheless, there still a lack of research that exploring the marketing communication attributes from the online version such as @ShopeeID. Therefore it is necessary to conduct research related to the fashion industry to improve the empirical findings related to the fashion industry.

\section{Theoretical Review}

Technology and also, information enables the creation of new products. The development of technology and information create a fast and dynamic mode. In the globalization, every individual especially the young individual would like to follow the trend, look goods, keep on updating the new fashion and changing mode, looking for innovativeness and creativity (Hirschman, 1980). Nevertheless, regards to the responsive and varieties of choices in e-commerce, consumers require more demand for fashion.

The youth have a lot of leisure time, which they will utilize to look for an updated fashion from social media, the fashion of their idol wear. These are the reason that the young individual always wants to have an up to date and unique fashion to wear (Tian, Bearden, \& Hunter, 2001). Fashion is how they could show their existence within the community.

Fashion is a reflection of the images, relates to who they are. Fashion communicates, what the youth wants to be, and how they want to be with it. It is a projection of him or herself (Chamil Viranga, 2011). A right image is an essential factor presented, good perception and the right image are good for his or her career in the future. Fashion is not only related to clothes to cover the body, but also a mode that could make a unique appearance. Therefore there is always innovation in the fashion industry (Arnold \& Reynolds, 2003).

In the e-commerce, online fashion retail proposing information related to the product, the price and also the picture could reflect the design and the mode of the clothes. The consumer or the target consumer could see the design from their mobile phone (Colliander \& Dahlen, 2011). Online fashion is a mean of communication that is growing know this since the consumer could analyze and also observe the new trend from the pictures delivered 
from the social media in their mobile phone.

Fashion is also related to the price that should help the consumer pay to have the clothes. Therefore the ecommerce and online fashion social media are also delivering information related to the price of the clothes.

This research is trying to explore the attributes delivered from @ShopeeID to the targeted consumer. This research is necessary since the behavior of the consumer is changing from the older generation that like to shop and going to the mall, shopping fashion in the store, moving to the new generation that is fond of browsing via the Internet, the social media and buying the fashion from the application like @ShopeeID.

The offline retail and shopping experience is different compared with the online shopping experience, in the online shopping experience the consumer has the opportunity to look for varieties of choices, this is different from the offline retail which only selected choices available in the store.

Another difference also related to complaint management, when consumers are shopping in the offline retail store, the consumer could deliver a complaint directly to the stores. Bringing the clothes and change or modify the clothes in the store. The consumer could also relate with the other consumer within the application (Wolny \& Mueller, 2013).

It is a different way around since the consumer did not meet the direct seller, but only receive the clothes in the products. There is an opportunity that the products did not match the expectation. Therefore, the detail of the attribute should be explored. In this research, we could see the detail attribute delivered from the retail fashion ecommerce to targeted consumers.

Furthermore, Indonesian consumer behavior shifting from offline shopping to online shopping. The online sales compared to the total retail sales are growing from $7.4 \%$ in 2015 to $8.7 \%$ in 2016 , and there is a projection that the numbers will grow in 2021 and reach 15. 5\% (Statista, 2018). The shifting pattern especially happens in the behavior of the young people of Indonesia (Suyanto, Subiakto, \& Srimulyo, 2019).

In this new era, the consumer, and also the retail fashion industry is changing (Sundström, Hjelm-Lidholm, \& Radon, 2019). The new generation, the information, and technology enable the consumers to show and compare the choices in their gadget before buying the product. The comparison also requires less effort compared with going to the variety of store, since the cloth images, the price and also additional information related to the clothes available in the smartphone, in the hand of the consumers, all of this flexibility that drives the growing demand for online shopping.

The young consumer like to hang out in the mall and looking for fashion, but the patterns show that they are enjoying looking for, searching and browsing the fashion in the gadget. Furthermore they only have to click on the gadget, smartphone, and laptop to buy any product they want. Fashion is a lifestyle component for selfexpression and the identity of the youth (Dahana, Miwa, \& Morisada, 2019).

Variety of choices is one of the benefits of using online shopping services. The consumer could compare new design and also the price, and it could also access the fashion not only in Indonesia but also worldwide. Therefore, social media is necessary for online shopping.

Research conducted by (Ladhari, Gonthier, \& Lajante, 2019) shows that there is four approaches for Gen Y online shopping which are the trending shopping, pleasure shopping, price shopping, and brand shopping. Research explores how online fashion shoppers perceive the relevance of social media marketing activities. The results show that social media marketing strategy less effective. Nevertheless, social media could post online customer reviews that important for retailers, service providers, and consumers. Posting on the social media, reviews could influence product sales in a particular industry such as restaurants, technology products, and books (Chevalier \& Mayzlin, 2006).

Not all review is effective; the quality of review is essential to influence the credibility of the review and influence the consumers' behavior (Chakraborty and Bhat, 2018). Posting in social media mostly unstructured, which makes the consumer need to interpret the unstructured data set (Fillieri, 2018).

Another important for reviews is the background of the reviewer. If the reviewers have many followers, therefore the comment more credible (Cheng \& Ho, 2015), and useful to support the products or services in the social media. Finally, all of this review will influence the consumer press toward the information delivered in the social media (Stouthuysen, Teunis, Reusen, \& Slabbinck, 2018). The more trusted the review, therefore it could influence the likelihood for the promotion to be effective. Therefore it is necessary to explore the attributes of the online fashion retail, to develop a typology of the consumers and the promotion delivered for the target markets.

This research explores the new consumer behavior related to the attribute proposed by the online fashion retail channel. The findings will be beneficial to improve the body of knowledge of retail and fashion consumer behavior.

\section{Research Method}

@ ShopeeID is one of the growing e-commerce fashion retail. The data extracted from @ ShopeeID for September 2018. Total 1761 tweet processed for further exploratory factor analysis. The dataset represents the marketing communication@ @ShopeeID. The data preparation starts with cleaning the data from the second 
posted dataset, the exploratory factor analysis conducted with the Provalis Software (Figure 1)

\begin{tabular}{|c|c|c|c|}
\hline $\begin{array}{c}\text { Data Extraction } \\
\text { @ShopeelD }\end{array}$ & Data Preparation & $\begin{array}{c}\text { Exploratory Factor } \\
\text { Analysis }\end{array}$ & Findings \& Discussion \\
\hline 1761 Dataset & $\begin{array}{c}1761 \text { Tweet \& } \\
0 \text { ReTweet }\end{array}$ & 100 Themes & Variety of Promotion \\
\hline
\end{tabular}

Figure 1. Research Process

Exploratory factor analysis conducted to analyze the relationship within the tweet dataset to search and find the insight within the data (Wijanto, 2008) (Hair, Anderson, Tatham, \& William, 1998). The method selected since there is a lack of theory related to the fashion retail e-commerce, therefore tweet data set relevant expose the real phenomena about the @ShopeeID marketing communication to the targeted market. The method had been conducted for the coffee shop (Harwani \& Sihite, 2019), hospitality (Nugroho, 2018b) (Arissetyanto Nugroho, Sihite, \& Harwani, 2019), online transportation (Sihite, 2019a), kitchen application (Sihite, 2019b), National Tourism Organization (Sihite \& Nugroho, 2018) (Nugroho \& Sihite, 2018) (Nugroho, 2017), education (Nugroho \& Janfry Sihite, 2015a) (Nugroho \& Janfry Sihite, 2015b), airline (Sihite, Harun, \& Nugroho, 2015) (Nugroho \& Janfry Sihite, 2015), banking (Nugroho \& Sihite, 2016) (Nugroho, 2018a), ready to drink tea (Nugroho, 2018c).

The exploratory factor analysis will expose themes from the dataset since the technique reduce the data complexity to a specific dimension (Campbell, Pitt, Parent, \& Berthon, 2011). The Provalis Research Software consists of the QDA Miner that could identify the relationship between keywords with the concurrence method (Silver \& Lewins, 2014).

\section{Results and Discussion}

On 13 September $2018 @$ ShopeeID receiving complaints from consumers. One of them is@Aby_izh that said he got this order notification from @ShoppeeID that the order is completed. However, the customer did not receive the products. Moreover, the customer asks whether the purchased is expired? In the same date, @ShopeeID delivering an apology for the problems. Moreover, if the order from the customer has not finished the guarantee is available, and the customer calls Shopee for the refund and that the request will be forwarded to the producer. The customer also encourages to call the seller and @Aby_izh respond; the shop did respond to the customer after the order received. The tweet delivered on September 15, 2018.

Furthermore, @ShopeeID also respond to one of the customer with the username@apasihlogajelas, the nick of the username change into@shinryujien. The content of the reply that system maintenance occurred. Therefore the voucher is available, but the customer can use the other Shopee promotion and voucher.

@ShopeeID reply to the complaint from@Luntanglantung on 27 September 2018. The content of the information, there is system maintenance. The voucher cannot be used for today. Moreover then (a) Luntanglantung answer the response with a question, if the voucher discount is 50,000, is it open automatically or is also non-active? Nevertheless, there are no respond regards to the info. @ShopeeID is also receiving a compliment from a customer@loacliq which satisfied shopping @ShopeeID. On September 2018 (a) ShopeeID respond the posting uploaded on 6 May 2018. Farmer's market launches the store in the (a) ShopeeID, and there is a discount of $35 \%$.

The content of the tweet, do the farmer's markets sell the product? Because they did not send the product that he had bought, and the seller did not respond to chat. @.ShopeeId respond to that tweet by asking the customer to inform the number of the order so, the Shopee could check the status of the process of delivery. @ShopeeID ask the customer to send the number of the order, but there is no other response from @ShopeeID.

There is also a customer with the user name @youbian, complaining about the Shopee voucher that cannot be used. The response from Shopee is that the customer should make sure that the code for the voucher is available and have not been used before. The account and the mobile phone Is the same. Moreover, the customer still can use the other voucher promotion from Shopee.

Shopee is also promoting a program on 21 September and 27 September 2018. The promotion is the cashback if you are buying a product in Shopee. The customer will get back cash for 100,000 rupiahs Moreover, on 27 September, the promotion is a discount until $80 \%$ and a cashback until 75.000 in the culinary party, the promotion available until 30 September.

Shopee also making an exciting promotion for the customer, one of the promotion is Grand Fashion Bazaar on 21 September until 2 October. Discount until 95\%, cashback until 100,000, and also a Top Brand Sale. The customer also could get a free delivery voucher.

Shopee is also launching an exclusive program on 13 September. All the JBL speaker discount until 800,000 , cashback 100,000 and free delivery and also a super flash sale and super deal until 70\%. Shopee even doing a super promotion from the handphone product Honor! Exclusive launch Honor 9E with a flash sale starting from 2.399.000 rupiah. 
@ShopeeID is responding a tweet from @,AnggiNoviaranis that delivering gratitude for the participation on joining the going Shopee on 23 September 2018. @ShopeeID also respond an account @ekaristi77 that already redeemed a coin in daily games OOTD and from some outfits, but he received nothing on 22 September 2018.

Furthermore, @ShopeeID replying you do not have to worry, please wait for another 24 hours after you are redeeming your point. You will get a notification and earned the prize for an outfit OOTD, and please check your application regularly.

(a) ShopeeID also frequently using a YouTube content to promote the free online shopping application, one of the video content from YouTube is "Cobain Yuks Episode." The content of YouTube is reviewing the food and the goods that are viral. One of them in the episode of 20, which is uploaded on 6 September 2018 titled Bluetooth speaker JBL, the best ft Sobat Hape.

The exploratory research @ShopeeID show that twitter @ ShopeeID is promoting a program that is related to the Shopee application. There is a cashback program, promoting an excellent and also a product at Shopee, and also promoting a game that engaging the Shopee user to interact and collecting the Shopee prizes.

Shopee is also integrating the promotion with the other application like YouTube. There is a short video related to promoting an excellent and also a food that is linked in Shopee. All of this related to improve the user satisfaction of Shopee, trying the application of Shopee and finally buying the product in the Shopee.

There is also a complaint related to shopping services. It seems that the coucher that is a part of the promotion is receiving some complaints from the user that have difficulties on redeeming the point and also using the voucher. Nevertheless, the interaction of the comment did not finish yet; Shopee did not answer all of the replying questions from the customer.

\section{Conclusion}

The findings of the research showed that there are some of the marketing elements delivered by @ShopeeID, which are the promotion, the price, the product, the process. @ShopeeID utilized social media to improve the promotion, the utilization of social media improve the responsiveness to deliver the updated fashion mode to the targeted market.

There is also complaint aimed to improve the relational benefit for the Shopee user. This relational communication enhances the real-time complaint and influences the @ShopeeID to respond quickly, regards to the complaint. Further research on mapping the complaint delivered from the customer to Shopee needs to be conducted. This complaint will be beneficial for Shopee to prepare the most frequently commented topics and make proper procedure and improvement to reduce the complaint.

Furthermore, research on the qualitative aspect of the design and also the product delivered by @ ShopeeID should be conducted to be able to explore the insight related to the growing fashion model in fashion retail. Since this research only exploring the tweet delivered, therefore, exploration toward the images from the tweet will improve the knowledge of the fashion retail application.

\section{References}

Arnold, M. J., \& Reynolds, K. E. (2003). Hedonic shopping motivations. Journal of Retailing, 79(2), 77-95.

Campbell, C., Pitt, L. F., Parent, M., \& Berthon, P. (2011). Tracking Back-Talk in Consumer-Generated Advertising: An Analysis of Two Interpretative Approaches. Journal of advertising research, 51(1), 224. doi:10.2501/jar-51-1-224-238

Chamil Viranga, R. (2011). An empirical investigation of fashion consciousness of young fashion consumers in Sri Lanka. Young Consumers, 12(2), 121-132. doi:http://dx.doi.org/10.1108/17473611111141588

Cheng, Y.-H., \& Ho, H.-Y. (2015). Social influence's impact on reader perceptions of online reviews. Journal of Business Research, 68(4), 883-887.

Colliander, J., \& Dahlen, M. (2011). Following the Fashionable Friend: The Power of Social Media - Weighing the Publicity Effectiveness Of Blogs versus Online Magazines. Journal of advertising research, 51(1), 313. doi:10.2501/jar-51-1-313-320

Chevalier, J. A., \& Mayzlin, D. (2006). The effect of word of mouth on sales: Online book reviews. Journal of marketing research, 43(3), 345-354.

Dahana, W. D., Miwa, Y., \& Morisada, M. (2019). Linking lifestyle to customer lifetime value: An exploratory study in an online fashion retail market. Journal of Business Research, 99, 319-331. doi:10.1016/j.jbusres.2019.02.049

Euromonitor. (2019a). Digital Commerce in Indonesia. Retrieved from Euromonitor International

Euromonitor. (2019b). Digital Consumer in Indonesia. Retrieved from Euromonitor International

Euromonitor. (2019c). What Asia Can Teach The Rest Of The World About Digitally Inspired Commerce. Retrieved from Euromonitor International

Hair, J. F., Anderson, R. E., Tatham, R. L., \& William, C. (1998). Multivariate data analysis.

Harwani, Y., \& Sihite, J. (2019). The Marketing Mix Element of the Coffee Shop. A Case Study 
(a)CoffeeBeanIndo. European Journal of Business and Management, 11(18), 169-174. doi:10.7176/EJBM/11-18-20

Hirschman, E. C. (1980). Innovativeness, novelty seeking, and consumer creativity. Journal of Consumer Research, 7(3), 283-295.

Ladhari, R., Gonthier, J., \& Lajante, M. (2019). Generation Y and online fashion shopping: Orientations and profiles. Journal of Retailing and Consumer Services, 48, 113-121. doi:10.1016/j.jretconser.2019.02.003

Nugroho, A. (2017). ASEAN Tourism Marketing Communication Attribute: An Exploratory Research at Goaseantv. European Research Studies Journal, XX(3).

Nugroho, A. (2018a). Analisis Faktor Eksploratori Layanan @syariahmandiri. Jurnal Ekonomi, XXIII(3), 376388.

Nugroho, A. (2018b). The Hospitality Marketing Communication Attribute. A Case Study@ @hrhbali (Hard Rock Hotel Bali). Journal of Marketing and Consumer Research, 50.

Nugroho, A. (2018c). The Role of Price in Deciding to Purchase Ready-to-Drink Tea. Jurnal Manajemen, XXII(03), 380-394.

Nugroho, A., \& Sihite, J. (2015a). Is It A Relational Marketing Strategy? Cluster Analysis @.Universitasmercubuanajakarta Facebook Post and Comment. Manajemen MIX, V(2).

Nugroho, A., \& Sihite, J. (2015b). Is It Traditional or Contemporary Marketing Strategy? A Textual Cluster Analysis@MercuBuana_Reg. Mediterranean Journal of Social Sciences, VI(5).

Nugroho, A., \& Sihite, J. (2015). Tweeting And Retweeting Tourism And Airline Service Attributes. Thomson Reuter Indexed Proceeding. International Geographical Union \& Lombok International Conference. University Mataram.

Nugroho, A., \& Sihite, J. (2016). Exploratory Factor Analysis Syariahmandiri and Bankmandiri Service Attributes 2015. . The Social Sciences, 11, 4896-4901.

Nugroho, A., \& Sihite, J. (2018). ASEAN Tourism Destination: A Strategic Plan. European Research Studies Journal, 21(3), 293-298.

Nugroho, A., Sihite, J., \& Harwani, Y. (2019). The Promotion, Product and the People of Luxurious Hotel: A Case Study@hrhbali 2018. Journal of Tourism, Hospitality and Sports, 41, 73-78. doi:10.7176/JTHS/41-01

Sihite, J. (2019a). The Online Transportation Marketing Mix CoCreation: A Case Study@gojekindonesia. Journal of Marketing and Consumer Research, 57, 44-50. doi:10.7176/JMCR/57-05

Sihite, J. (2019b). The Promotion and Process Attribute for the Kitchen Appliance. A Case Study @KitchenAid_Indo. European Journal of Business and Management, 11(18), 164-168. doi:10.7176/EJBM/11-18-19

Sihite, J., Harun, T. W., \& Nugroho, A. (2015). The Low Cost Airline Consumer Price Sensitivity. An Investigation on The Mediating Role of Promotion and Trust in Brand. International Research Journal of Business Studies, VII(3).

Sihite, J., \& Nugroho, A. (2018). Exploring the Indonesian Tourism Destination via Indonesia.Travel @indtravel.

Silver, C., \& Lewins, A. (2014). Using software in qualitative research: a step-by-step guide.

Sirumapea, A., Ramdhan, S., \& Masitoh, D. (2017). Aplikasi Augmented Reality Katalog Baju Menggunakan Smartphone Android. JURNAL SISFOTEK GLOBAL, 7(2).

Statista. (2018). E-commerce share of total global retail sales from 2015 to 2021.

Stouthuysen, K., Teunis, I., Reusen, E., \& Slabbinck, H. (2018). Initial trust and intentions to buy: The effect of vendor-specific guarantees, customer reviews and the role of online shopping experience is. Electronic Commerce Research and Applications, 27, 23-38.

Sundström, M., Hjelm-Lidholm, S., \& Radon, A. (2019). Clicking the boredom away - Exploring impulse fashion buying behavior online. Journal of Retailing and Consumer Services, 47, 150-156. doi:10.1016/j.jretconser.2018.11.006

Suyanto, B., Subiakto, H., \& Srimulyo, K. (2019). Data of the patterns of youth local brand product consumption through online shopping. Data in Brief, 23, 103723. doi:10.1016/j.dib.2019.103723

Tian, K. T., Bearden, W. O., \& Hunter, G. L. (2001). Consumers' need for uniqueness: Scale development and validation. Journal of Consumer Research, 28(1), 50-66.

Wijanto, S. H. (2008). Structural Equation Modeling dengan LISREL 8.8: Konsep dan Tutorial.

Wolny, J., \& Mueller, C. (2013). Analysis of fashion consumers' motives to engage in electronic word-of-mouth communication through social media platforms. Journal of Marketing Management, 29(5/6), 562-583. doi:10.1080/0267257X.2013.778324 